\title{
Concern over 'invisible problem' of HIV blood in developing countries
}

Paris. Almost ten years after the industrialized world began to screen all blood used in transfusions for human immunodeficiency virus (HIV), as many as one in ten seropositives in developing countries are still being infected through this route.

Aware of the continuing problem, the World Health Organisation(WHO) last week approved the setting up of a new blood safety unit. But some observers fear that political wrangling within WHO, combined with cutbacks at the United $\mathrm{Na}$ tions (UN), will deny the unit the funds and staff that it needs to focus both international attention and resources on the problem of blood safety.

The screening of blood for HIV is patchy in the developing world. Even in Côte d'Ivoire, for example, which has one of the most advanced systems, such screening is routine only in the capital Abidjan, and in two other cities.

A combination of the lack of screening with high levels of infected donors turns transfusion into a form of Russian roulette. A survey carried out by WHO in 1990 , for example, showed that centres in Kinshasa, Zaïre, screened fewer than a quarter of blood units for HIV, even though about five per cent of donors were seropositive.

Receiving a transfusion of HIV-contaminated blood carries a roughly 95 per cent risk of HIV infection, compared with a 0.1 to 1.0 per cent risk through sexual transmission. "Endorsing risky transfusion is as morally acceptable as saying that it's okay for an antibiotic to kill one-third of patients", says one French scientist.

But as a result, transfusion still accounts for 5 to 10 per cent of HIV infections worldwide, according to Jean Emmanuel, of the WHO Global Programme on AIDS. In some developing countries, the figure is even higher, he says.

Despite this, blood safety has yet to be given priority by the international community. "There is a sort of agreed invisibility to the problem," says Daniel Tarantalo, director of the International AIDS Programme at the Harvard School of Public Health. "Countries are embarrassed to admit their blood is unsafe, while the international agencies don't dare expose individual countries, as they would be held responsible for not providing enough of the right support."

Some WHO officials also feel that money is better spent on preventing sexual transmission of HIV. Funding for HIV screening of blood is being phased out of WHO's Global Programme on AIDS, for example. "There is generally less and less money available for screening," says Souleymanc M'Boup, head of the laboratory of bacteriology and virology at the Aristide Le Dantec University Hospital in Dakar, Senegal.

Similarly, a Global Blood Safety Initiative, announced by WHO five years ago, never took off. According to one WHO official, its credibility was destroyed by underfunding and understaffing. "GBSI was a valid approach," says Tarantalo. "But

\section{IMAGE UNAVAILABLE FOR COPYRIGHT REASONS}

\section{Blood donation in Africa: funds for screening} are still lacking.

inter-institutional tensions were insurmountable."

One senior WHO official admits that what he describes as a "lack of coordination" among international organizations is a major problem. For example, UN agencies have, despite almost a year of negotiation, yet to agree how to supply HIV test kits to Burma, where two-thirds of blood goes unscreened. "Institutional mandates are unclear, and each agency has competing priorities within its budgets," says Tarantalo.

Another problem has been straightforward bungling by aid agencies. For example, screening equipment was sent to Ethiopia without local laboratory staff having been trained to use it.

Similarly, WHO has sent reagents with a two-month shelf life to countries where they are not being used for six months. Reagents requiring refrigeration are often left in the sun waiting for customs clearance.

WHO's approval of the new blood safety unit is a victory for Fernando Antezana, who has fought for greater emphasis on blood safety since he became assistant directorgeneral of WHO earlier this year.

Many applaud his stand; "we are now on the brink of getting our act together," says one WHO official. But others remain concerned that Antezana may not be able to win sufficient funding for the unit, particularly at a time when programmes and posts are being cut back throughout the UN.

If Antezana does obtain the money he needs, the practical tasks he faces will still nonetheless be formidable. A lack of HIV screening is usually only a symptom of an already impoverished transfusion service, and these services need to be revamped before screening systems can work well.

Senegal, for example, has one of the few comprehensive HIV screening programmes in Africa, primarily because it had an efficient blood service in operation before the dangers of the virus were known, says M'Boup.

In contrast, the WHO survey in Kinshasa in 1990 showed that half the blood centres had no refrigeration, that 90 per cent lacked facilities for testing donor/recipient compatibility and that bacterial contamination of blood was "common".

One major plank of any aid programme will be the building of production facilities for blood substitutes, says Jean-Jacques Fournel, director of blood transfusion at the Pitié-Salpêtrière hospital in Paris. Many developing countries use blood unnecessarily, he says, as it is cheaper than more appropriate alternatives, such as saline solutions or colloids, which have to be imported.

In addition, Fournel says that wellequipped screening programmes often founder because they fail to take local culture sufficiently into account. In particular, procedures are often not followed because of a lack of proper supervision and training. Africans often prefer to make decisions by consensus rather than giving orders to one another, he says. "It may sound reactionary, but you need foreign supervision to get things done."

Declan Butler

\section{New setback for India's nuclear programme}

New Delhi. India's nuclear power programme, already truncated due to financial cutbacks, suffered further last month when a 1500-tonne concrete dome of a reactor containment building under construction at Kaiga in Karnataka state partly collapsed.

No radioactivity was released, as nuclear fuel had not been transferred to the building, and the 14 workers injured required no more than first-aid treatment. However the incident, coming less than a year after a damaging fire at another atomic plant in Narora in Uttar Pradesh, has given fresh ammunition to the state's environmental groups, which are opposed to the plant's location in virgin rain forest. 